\title{
Priority Business Partner of Russia: China, Germany or USA
}

\author{
V.V. Smirnov \\ Chuvash state University \\ Cheboksary, Russia \\ walera712006@mail.ru \\ E.N. Kadyshev \\ Chuvash State University \\ Cheboksary, Russia \\ A.G. Suchkova \\ Chuvash State University \\ Cheboksary, Russia
}

\author{
V.L. Semenov \\ Chuvash state University \\ Cheboksary, Russia
}

\begin{abstract}
The article reveals the relevance of the problems of maintaining the rate of economic growth of individual countries, creating favorable conditions for doing business in a period of decline of the dynamics of growth of world trade and strengthening of global competition. As a result of comparative analysis of business conditions in Russia relative to China, Germany and the United States, competitive advantages in property registration and insolvency recognition are determined. The difficulty in doing business in Russia, at least, is associated with the underdevelopment of institutions. The forecast values of economic growth dynamics showed the priorities of Russia, in comparison with China, Germany and the United States - the current account balance, military spending and gross savings. The research highlights the main competitive advantages of Russia relatively to China, Germany and the United States in the form of: ease of registration of property and recognition of insolvency of firms dominating of state corporations; purposefully oriented development of entrepreneurship in the form of an actor serving the economic interests of state corporations, political interests of the state, including the military-industrial complex, extractive industry, construction industry, financial and insurance sector.
\end{abstract}

Keywords: state corporations, economic growth dynamics, competitive advantages, national projects, forecast prospects, comparative analysis, growth rates, business conditions

\section{INTRODUCTION}

In the context of a slowdown of world trade, the deep specialization of individual countries increases global competition [1,2]. Countries that do not withstand global competition leave the world market and fall into stagnation.
For Russia, which has almost exhausted its political, economic and institutional potential, the choice of an international business partner for joint development remains the only way to resist global competition and ensure stable economic growth.

Among the potential international business partners China and Germany should be identified which are the industrial giants of Asia and Europe (sixth technological order). Russia links Europe and Asia by its geopolitical and economic space.

At the same time, it should be taken into account the potential of the US economy, the largest in the world by nominal GDP (about a quarter of the world nominal GDP in US dollars since the end of world war II). The active influence of the United States on the growth rate of the world economy and the global world order requires assessing its potential as a business partner for Russia.

Assessing China, Germany and the United States as international business partners, it is necessary to consider the negative phase of the cyclical development of the world economy-the recession and, as a consequence, the decline in the "value" of their industrial potential. The fall in share prices of large companies of industrial giants leads to a decrease in their capitalization, production volumes, loss of markets, unemployment, etc. These phenomena have an impact on countries dependent on the stability of commodity exports [3, 4].

"Morgan Stanley" has cut its global share allocation to its lowest level for five years and downgraded its investment 


\section{A. Business Opening}

recommendation. It was recorded that stock prices slightly went up in Hong Kong and South Korea, while they fell in Japan and China. S\&P500 futures (high, oil fell below \$60) US \$ per barrel Brent [5]) changed slightly after the benchmark closed to almost flat. 10-year Treasury Bond yields hit $2.08 \%$ [6].

Investors "Senti" believe the economic downturn in Germany is inevitable. According to the survey an index measuring current conditions and expectations for Europe's largest economy has fallen to its lowest level for nearly a decade. Germany's high dependence on exports and the Chinese market means more uncertainty until the customs dispute between China and the United States is settled. German industrial production showed monthly growth in May 2019, but in annual terms it is still declining [7].

Chinese growth slowed to $6.2 \%$ last quarter from $6.4 \%$ in the first quarter of 2019. [8] Nominal GDP growth in the second quarter of 2019 rose to about $8.1 \%$ from $7.8 \%$ in the previous three months, resulting in a slightly higher GDP deflator of $1.9 \%$ [9].

In a recession, the stocks demand declines and the demand for "Treasury Bond" (T-Bond) drives up, which leads to pushing down yields not only for stocks, but for the T-Bonds too. The negative yield of T-bonds, if held to maturity, extends to more quantity of bonds, eroding potential returns for investors.

In Germany, $85 \%$ of the T-Bond market is in the "red zone". This means that investors are actually paying the German government $0.2 \%$ for the privilege of buying its underlying bonds. The German government retains 2 euros for every 1,000 euros borrowed over 10 years.

The US is one of the few developed countries that doesn't reduce T-Bonds yields below zero.

Therefore, the problem of choosing an international business partner in a global recession is currently important not only for the stagnant Russian economy, but also for all countries of the world as a whole. The recession in the world economy requires both developed and developing countries to take immediate measures to stabilize economic growth. The achieved marginal marginality of these countries forces them to pay attention to the possibilities of mutually beneficial cross-country cooperation in the field of doing Business (DB), which will significantly increase the possibility of overcoming the recession.

\section{METHOD}

According to the methodology "Doing Business, Measuring Business Regulations" [10] by The World Bank the following procedures: opening a business; registration of permits for construction; connection to a power source; registration of property rights; loan approval; protection of the rights of minority shareholders (minority shareholders); payment of taxes and fees; organization of international trade; contract enforcement; settlement of insolvency issues are distinguished.
The procedure regulating the time, costs and minimum security capital requirement, and establishing the ability to manage the business officially. The procedure includes the processes of all necessary approvals and licensing, the stages of obtaining permits and filling in the necessary notifications and checks for the company and employees by the authorized regulatory authorities.

\section{B. Registration of permits for construction}

The procedure includes a project justification of the time and cost of construction of the warehouse. The project justification includes: assessment of the quality of buildings, their compliance with construction standards; the mechanism of quality control and safety of the warehouse (structure); liability and insurance; requirements for certification of the warehouse.

\section{Connection to a power source}

The procedure required for connection and supply of electricity for the warehouse (construction) includes: submission of an application for connection to the relevant state Supervisory authorities; necessary checks and permits from distribution companies, other institutions; conclusion of a contract with the power supply company; work on external and final connection to the power source.

The main criterion for connecting to an electricity source is the reliability of the power supply company and the tariff formation transparency.

\section{Registration of property rights}

The procedure is obligatory for business, in order to realize the rights of ownership, use and disposal. Registration of property rights provides an opportunity to expand business, use the property as collateral, etc.

\section{E. Approval of the credit}

The procedure of approval of the loan is a necessary condition for obtaining the borrowed funds. It deals with the assessment of the legal rights of borrowers and lenders with respect to security measures and the presentation of credit information on collateral and bankruptcy.

\section{F. Protection of minority rights}

Procedure for protection of minority shareholders ' rights in case of conflict of interests arising in the process of corporate governance.

\section{G. Payment of taxes and fees}

The procedure of registration of the order of payment of taxes, fees and other mandatory contributions that the company must pay at the end of the tax period, as well as administrative measures in case of failure to meet deadlines and amounts of payment.

\section{$H$. International trade organization}

The procedure is related to the assessment of the time and cost (excluding tariffs) of documenting border compliance and international transport, as part of the overall process of exporting or importing goods. 


\section{The enforcement of the contract}

The procedure determines the time and cost of resolving a commercial dispute through the court of first instance (quality of trials). The quality and efficiency of the judicial system are evaluated.

\section{J. Settlement of insolvency issues}

The procedure includes an assessment of the timing, cost and results of proceedings in the case of insolvency of economic entities, as well as the strength of legal liquidation and reorganization rules.

\section{ANALYSIS}

A. The introduction of the business "Doing Business, DB"

The assessment of DB conditions is based on the comparison of stable $\left(\sigma^{2}=0\right)$ values of DB indicators of Russia, China, Germany and the USA according to the World Bank [11]. As a result of the assessment, the advantages and disadvantages of the Russian economy relative to China, Germany and the United States were revealed (table I):

1) advantages:

- registration of property rights: information transparency index;

- recognition of insolvency framework index the strength of insolvency;

TABLE I. STABLE $\left(\sigma^{2}=0\right)$ INDICATORS OF "DOING BUSINESS" IN RUSSIA, CHINA, GERMANY AND THE USA

\begin{tabular}{|c|c|c|}
\hline Indicator & $\begin{array}{c}\text { Country } \\
\text { Numeric } \\
\text { Code }\end{array}$ & $\begin{array}{c}2016 \\
- \\
2019\end{array}$ \\
\hline \multirow{4}{*}{$\begin{array}{l}\text { Work with construction permits: the index of the } \\
\text { regimes of liability and insurance }(0-2) \\
\text { (methodology DB16-19) }\end{array}$} & China & 2.0 \\
\hline & Germany & 0.5 \\
\hline & Russia & 1.0 \\
\hline & USA & 0.4 \\
\hline \multirow{4}{*}{$\begin{array}{l}\text { Work with building permits: quality control after } \\
\text { the construction index (0-3) (methodology } \\
\text { DB16-19) }\end{array}$} & China & 3.0 \\
\hline & Germany & 2.0 \\
\hline & Russia & 3.0 \\
\hline & USA & 3.0 \\
\hline \multirow{4}{*}{$\begin{array}{l}\text { Work with building permits: quality control } \\
\text { before construction index (0-1) (methodology } \\
\text { DB16-19) }\end{array}$} & China & 1.0 \\
\hline & Germany & 1.0 \\
\hline & Russia & 1.0 \\
\hline & USA & 1.0 \\
\hline \multirow{4}{*}{$\begin{array}{l}\text { Contract enforcement: alternative } \text { dispute } \\
\text { resolution }(0-3) \text { (methodology DB16-19) }\end{array}$} & China & 3.0 \\
\hline & Germany & 3.0 \\
\hline & Russia & 2.5 \\
\hline & USA & 2.5 \\
\hline \multirow{4}{*}{$\begin{array}{l}\text { Contract enforcement: attorney's fee (\% of claim } \\
\text { amount) }\end{array}$} & China & 8.7 \\
\hline & Germany & 6.6 \\
\hline & Russia & 11.5 \\
\hline & USA & 20.6 \\
\hline \multirow[t]{4}{*}{ Contract enforcement: cost (\% of claim amount) } & China & 16.2 \\
\hline & Germany & 14.4 \\
\hline & Russia & 16.5 \\
\hline & USA & 30.5 \\
\hline \multirow{4}{*}{$\begin{array}{l}\text { Contract enforcement: cost (\% of claim amount) } \\
\text { - evaluation }\end{array}$} & China & 81.9 \\
\hline & Germany & 83.9 \\
\hline & Russia & 81.6 \\
\hline & USA & 65.8 \\
\hline \multirow{3}{*}{$\begin{array}{l}\text { Contract enforcement: ship automation (0-4) } \\
\text { (methodology DB16-19) }\end{array}$} & China & 3.0 \\
\hline & Germany & 1.5 \\
\hline & Russia & 0.0 \\
\hline
\end{tabular}

\begin{tabular}{|c|c|c|}
\hline Indicator & $\begin{array}{l}\text { Country } \\
\text { Numeric } \\
\text { Code }\end{array}$ & $\begin{array}{c}2016 \\
- \\
2019\end{array}$ \\
\hline & USA & 2.2 \\
\hline \multirow{4}{*}{$\begin{array}{l}\text { Contract enforcement: legal costs (\% of claim } \\
\text { amount) }\end{array}$} & China & 5.0 \\
\hline & Germany & 5.4 \\
\hline & Russia & 5.0 \\
\hline & USA & 5.0 \\
\hline \multirow{4}{*}{$\begin{array}{l}\text { Contract enforcement: structure and procedure of } \\
\text { the court }(0-5) \text { (methodology DB17-19) }\end{array}$} & China & 5.0 \\
\hline & Germany & 4.50 \\
\hline & Russia & 3.0 \\
\hline & USA & 4.4 \\
\hline \multirow{4}{*}{$\begin{array}{l}\text { Contract enforcement: enforcement fees (\% of } \\
\text { claim amount) }\end{array}$} & China & 2.5 \\
\hline & Germany & 2.4 \\
\hline & Russia & 0.0 \\
\hline & USA & 4.9 \\
\hline \multirow{4}{*}{$\begin{array}{l}\text { Execution of the contract: execution of the } \\
\text { judgment (days) }\end{array}$} & China & 240.0 \\
\hline & Germany & 90.0 \\
\hline & Russia & 120.0 \\
\hline & USA & 10.0 \\
\hline \multirow{4}{*}{$\begin{array}{l}\text { The connection to the source of electricity: the } \\
\text { connection of tariffs and tariff changes (0-1) } \\
\text { (methodology DB16-19) }\end{array}$} & China & 0.0 \\
\hline & Germany & 1.0 \\
\hline & Russia & 1.0 \\
\hline & USA & 1.0 \\
\hline \multirow{4}{*}{$\begin{array}{l}\text { The connection to the power source: the financial } \\
\text { constraints aimed to limit outages }(0-1) \\
\text { (methodology DB16-19) }\end{array}$} & China & 0.0 \\
\hline & Germany & 1.0 \\
\hline & Russia & 1.0 \\
\hline & USA & 1.0 \\
\hline \multirow{4}{*}{$\begin{array}{l}\text { Connection to a power source: mechanisms for } \\
\text { monitoring outages }(0-1) \text { (methodology DB16- } \\
19 \text { ) }\end{array}$} & China & 1.0 \\
\hline & Germany & 1.0 \\
\hline & Russia & 1.0 \\
\hline & USA & 1.0 \\
\hline \multirow{4}{*}{$\begin{array}{l}\text { Connection to a power source: mechanisms for } \\
\text { restoring service (0-1) (methodology DB16-19) }\end{array}$} & China & 1.0 \\
\hline & Germany & 1.0 \\
\hline & Russia & 1.0 \\
\hline & USA & 1.0 \\
\hline \multirow{4}{*}{$\begin{array}{l}\text { The connection to the source of electricity: } \\
\text { regular monitoring }(0-1) \text { (methodology DB16- } \\
\text { 19) }\end{array}$} & China & 1.0 \\
\hline & Germany & 1.0 \\
\hline & Russia & 1.0 \\
\hline & USA & 0.6 \\
\hline \multirow{4}{*}{$\begin{array}{l}\text { Payment of taxes and fees: time to adjust } \\
\text { corporate income tax (weeks) (methodology } \\
\text { DB17-19)- evaluation }\end{array}$} & China & 10.0 \\
\hline & Germany & 10.0 \\
\hline & Russia & 50.0 \\
\hline & USA & 10.0 \\
\hline \multirow{4}{*}{$\begin{array}{l}\text { Protection of the rights of minority shareholders: } \\
\text { the extent of corporate transparency index }(0-10) \\
\text { (methodology DB15-19) }\end{array}$} & China & 9.0 \\
\hline & Germany & 7.0 \\
\hline & Russia & 8.0 \\
\hline & USA & 5.4 \\
\hline \multirow{4}{*}{$\begin{array}{l}\text { Protection of the rights of minority shareholders: } \\
\text { the extent of corporate transparency index (0-10) } \\
\text { (methodology DB15-19) - evaluation }\end{array}$} & China & 90.0 \\
\hline & Germany & 70.0 \\
\hline & Russia & 80.0 \\
\hline & USA & 54.0 \\
\hline \multirow{4}{*}{$\begin{array}{l}\text { Protection of minority shareholders' rights: } \\
\text { degree of corporate responsibility of Directors } \\
(0-10)\end{array}$} & China & 1.0 \\
\hline & Germany & 5.0 \\
\hline & Russia & 2.0 \\
\hline & USA & 8.6 \\
\hline \multirow{4}{*}{$\begin{array}{l}\text { Protection of minority shareholders ' rights: } \\
\text { degree of corporate responsibility of Directors } \\
(0-100) \text { - evaluation }\end{array}$} & China & 10.0 \\
\hline & Germany & 50.0 \\
\hline & Russia & 20.0 \\
\hline & USA & 86.0 \\
\hline \multirow{4}{*}{$\begin{array}{l}\text { Protection of minority rights: degree of } \\
\text { disclosure of the index }(0-10)\end{array}$} & China & 10.0 \\
\hline & Germany & 5.0 \\
\hline & Russia & 6.0 \\
\hline & USA & 7.4 \\
\hline Protection of minority rights: degree of & China & 10.0 \\
\hline disclosure of the index (0-100) - evaluation & Germany & 50.0 \\
\hline & Russia & 60.0 \\
\hline & USA & 74.0 \\
\hline
\end{tabular}


As a result of the analysis of DB indicators in Russia, the proximity of business conditions with the Chinese economy was revealed. On the one hand, registration of property rights and recognition of insolvency (insolvency) are quite easy, on the other hand low automation of courts in the enforcement of contracts, contract enforcement (structure and procedure of the court; fees for enforcement), short terms for payment of taxes, weak interest in reorganization of production and recognition of insolvency (partial sale prevails) are noticed.

The above conditions are favorable for criminal environment of the emergence of "one-day firms" and raiding.

A one-day firm is a legal person that has no actual autonomy, without the purpose of doing business, usually doesn't submit any tax reporting and registered at the address of mass registration, etc. Letter of the FTS of the Russian Federation from 11.02.2010 N 3-7-07/84.

Raiding is unfriendly absorption of the enterprise against the will of its owners.

To eliminate these phenomena, it is necessary to squeeze out a wide range of the above disadvantages, at least with regard to the enforcement of agreements and contracts, and to introduce a number of restrictions on enforcement fees and taxes, similar to the United States and Germany.

\section{B. Dynamics of economic growth}

To analyze the dynamics of economic growth of Russia, China, Germany and the USA we find the predicted values of the median and dispersion of growth rates of indicators of economic development for the period $2010-2020$. As a result of the analysis the dynamics of growth recession in China, Germany and the USA, and stagnation in Russia were revealed. The consequence of significant differences in the dynamics of growth was the limited direction of development of the Russian economy in the process of international cooperation with China, Germany and the United States (table 2): "Current account balance (\%of GDP)"; "Military spending (\%of GDP)"; "Gross savings (\%of GDP)".

2) disadvantages:

- contract enforcement: automation of courts;

- contract enforcement: structure and procedure of the court;

- contract enforcement: enforcement fees;

- payment of taxes and contributions: the time of adjustment the corporate income tax;

- index of reorganization proceedings;

- recognition of insolvency: index of start-up of production;

- recognition of insolvency: results-in the form of partial sale. 
TABLE II. FORECAST VALUES OF MEDIAN AND VARIANCE OF GROWTH RATES OF INDICATORS OF ECONOMIC DEVELOPMENT OF RUSSIA, CHINA, GERMANY AND THE USA 2010-2020.

\begin{tabular}{|c|c|c|c|c|c|}
\hline Indicator & $\begin{array}{l}\text { Country } \\
\text { Numeric } \\
\text { Code }\end{array}$ & $\begin{array}{c}\mathrm{Me}> \\
\mathbf{0}\end{array}$ & Indicator & $\begin{array}{l}\text { Country } \\
\text { Numeric } \\
\text { Code }\end{array}$ & $\begin{array}{l}6^{2}< \\
100\end{array}$ \\
\hline \multirow{2}{*}{ 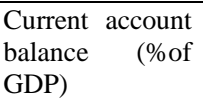 } & Germany & 5.9 & \multirow{4}{*}{$\begin{array}{lr}\text { GDP } & \text { per } \\
\text { capita. } & \text { PPP } \\
\text { (current. } & \text { doll. } \\
\text { USA) } & \end{array}$} & USA & 0.4 \\
\hline & Russia & 7.2 & & China & 1.9 \\
\hline \multirow{3}{*}{$\begin{array}{l}\text { Gross savings } \\
\text { (\% of GDP) }\end{array}$} & Germany & 3.5 & & Germany & 3.6 \\
\hline & Russia & 6.9 & & Russia & 37.9 \\
\hline & USA & 6.2 & \multirow{4}{*}{$\begin{array}{lr}\text { GNI } & \text { per } \\
\text { capita. } & \text { PPP } \\
\text { (current. } & \text { doll. } \\
\text { USA) } & \end{array}$} & USA & 0.96 \\
\hline \multirow{4}{*}{$\begin{array}{l}\text { GDP per capita } \\
\text { (current. doll. } \\
\text { USA) }\end{array}$} & Germany & 2.5 & & China & 1.9 \\
\hline & China & 11.6 & & Germany & 4.0 \\
\hline & Russia & 7.6 & & Russia & 37.4 \\
\hline & USA & 3.0 & \multirow{4}{*}{ 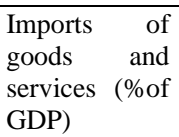 } & Russia & 4.4 \\
\hline \multirow{4}{*}{$\begin{array}{l}\text { GDP per capita. } \\
\text { PPP (current. } \\
\text { doll. USA) }\end{array}$} & Germany & 4.3 & & Germany & 19.89 \\
\hline & China & 9.1 & & USA & 39.0 \\
\hline & Russia & 5.7 & & China & 49.0 \\
\hline & USA & 3.0 & \multirow[t]{4}{*}{ Population } & Germany & 0.3 \\
\hline \multirow{4}{*}{$\begin{array}{l}\text { GNI per capita. } \\
\text { PPP (current. } \\
\text { doll. USA) }\end{array}$} & Germany & 4.0 & & China & 0.5 \\
\hline & China & 9.8 & & Russia & 0.1 \\
\hline & Russia & 5.9 & & USA & 0.7 \\
\hline & USA & 3.8 & \multirow{4}{*}{$\begin{array}{l}\text { Production. } \\
\text { value added } \\
\text { (\%of GDP) }\end{array}$} & China & 2.1 \\
\hline $\begin{array}{l}\text { Military } \\
\text { spending } \quad \text { (\%of } \\
\text { GDP) }\end{array}$ & Russia & 2.4 & & USA & 7.8 \\
\hline \multirow{4}{*}{$\begin{array}{lr}\begin{array}{l}\text { Imports } \\
\text { goods }\end{array} & \begin{array}{r}\text { of } \\
\text { and }\end{array} \\
\text { services } & (\% \text { of } \\
\text { GDP }) & \end{array}$} & Germany & 1.8 & & Germany & 13.0 \\
\hline & China & 1.88 & & Russia & 19.7 \\
\hline & Russia & 0.29 & \multirow{4}{*}{$\begin{array}{l}\text { Research and } \\
\text { development } \\
\text { expenditure } \\
\text { (\%of GDP) }\end{array}$} & USA & 1.9 \\
\hline & USA & 2.68 & & Germany & 7.9 \\
\hline \multirow{3}{*}{$\begin{array}{l}\text { Inflation. GDP } \\
\text { deflator (annual. } \\
\% \text { ) }\end{array}$} & Germany & 12.25 & & Russia & 24.16 \\
\hline & Russia & 68.8 & & China & 54.6 \\
\hline & USA & 18.7 & \multirow{4}{*}{$\begin{array}{l}\text { Final } \\
\text { consumption } \\
\text { expenditure } \\
\text { (\%of GDP) }\end{array}$} & Germany & 0.7 \\
\hline \multirow{3}{*}{$\begin{array}{l}\text { Inflation. } \\
\text { consumer prices } \\
(\text { annual \%) }\end{array}$} & Germany & 14.8 & & USA & 1.3 \\
\hline & Russia & 0.6 & & Russia & 9.7 \\
\hline & & & & China & 11.3 \\
\hline
\end{tabular}

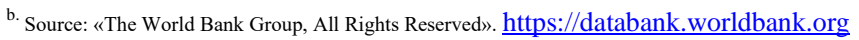

The stagnant Russian economy maintains a current account balance through military spending, including exports of defense products, as well as growth in gross savings caused by the "budget rule" and the inflation targeting policy of the Central Bank of the Russian Federation.

Budget rule is that Ministry of Finance of the Russian Federation directs additional oil and gas revenues (in excess of the price of 40 USD per barrel of Urals oil) to the purchase of currency, which is credited to the National Welfare Fund.

\section{DISCUSSION OF RESULTS}

Comparison of stable values of DB indicators of Russia showed proximity to DB conditions of China. Easy registration of property rights and recognition of insolvency (insolvency) allows you to reorient the business to growing market segments quickly. Under the conditions of state corporations' monopolies $[12,13]$, there is no type of business activity available for attracting credit funds in the high-margin sectors of the Russian economy.

For example, the growth of more than 6\% in 2018 was demonstrated by wholesale and retail trade of vehicles (cars and motorcycles) and their repair, financial and insurance activities, hotel business and catering. Among these three activities, only financial and insurance have a sufficiently large share (contribution to GDP growth-0.247 p. p.), commensurate - with public administration and military security (growth-3.46\%, contribution to GDP growth-0.241 p. p.); mining (growth-3.84\%, contribution to GDP growth 0.372 p. p.); construction (growth- $4.66 \%$, contribution to GDP growth-0.256 p. p.) [14].

Mining, construction, financial and insurance activities, public administration and military security, produced about $34 \%$ of GDP in 2018 (almost half of its growth, estimated at $2.3 \%$ ). This specialization can be explained not only by the raw material structure of the economy, but also by the high share of state corporations, whose marginal income is usually subsidized by the state $[15,16]$.

From 2019, the construction industry will increase the profitability of the financial and insurance sector through the " escrow account - the purchase or sale of real estate, including land; the purchase or sale of goods, works, services, as well as rights to the results of intellectual activity; the acquisition or sale of shares, interests.

The Central Bank of the Russian Federation's policy of improving the banking sector has led to the same "state corporations", but in the financial and insurance sectors of the economy. Thus, an acceptable form of DB in Russia is a state corporation in the military-industrial complex [17], the financial and insurance sector, the mining industry and the construction industry.

The resumption of economic growth in Russia, after the stagnation and recession of 2013-2017, becomes a more difficult task than overcoming the crisis of 2009 , due to the dominance of state corporations, requiring a larger mobilization of financial resources, the lack of new sources of growth, prolonged sanctions, etc. [18].

There is a need to develop an adapted comprehensive plan for the economic development of the country, taking into account the income and expenses of the consolidated Federal and regional budgets, the budgets of large state corporations and state banks, as well as other non-budgetary organizations with state participation at the Federal, regional and municipal levels [19]. The introduction of an adapted comprehensive economic development plan strengthens the role of state corporations, shifting priorities from privatization of large companies to their nationalization $[20,21]$.

The combination of advantages and disadvantages of DB of Russia stimulates the emergence of "one-day firms" and raider seizure of business [22], shifting the priorities of economic development towards state corporations.

The analysis of the forecast dynamics of economic growth in Russia, China, Germany and the United States revealed the priority in maintaining the current account balance through military spending [23] and the growth of gross savings.

The implementation of the Central Bank of the Russian Federation policy of inflation targeting, the active OFZ the Ministry of Finance of the Russian Federation in terms of fiscal rules increased the International reserves of the Russian Federation. Thus, Russia came to the second position after China [24] (relative to Germany and the United States) in 
terms of median GDP growth rates and GNI per capita by PPP.

The transition of Russia from a stable trend of economic growth to stagnation, due to the raw material structure, weak institutions [25], sanctions pressure, etc. [26], showed the need in the conditions of the global recession to use international cooperation in the field of energy actively. The forecast values of the median and variance of growth rates of indicators of economic development of Russia, China, Germany and the United States 2010-2020 allow us to identify Germany as the optimal, but ambitious, technological driver [27, 28]. The new interaction between Russia and Germany can be aimed at the formation of a model of organization of state institutions [29, 30] and support centers for export and investment activities abroad, based on the principle of priority and, to a greater extent, the acquisition of advanced technologies.

\section{CONCLUSION}

A comparative analysis of the market conditions and assessment of the dynamics of growth of the Russian economy with China, Germany and the United States revealed the scarce advantages of the Russian economy. They are easy registration of property rights and recognition of insolvency, which in a stagnant commodity economy, dominated by state corporations, do not stimulate business development as well as ensure economic growth.

The development of Russian business is associated with its ability to serve the interests of state corporations concentrated in the sectors of the economy related to mining, construction, financial and insurance activities, public administration and military security, creating more than $30 \%$ of GDP and half of its growth. At the same time, the problems of privatization of large state corporations and denationalization of the economy, in the conditions of concentrated raw material model of the Russian economy and stagnation, lose their relevance.

\section{REFERENCES}

[1] C. Constantinescu, A. Mattoo, and M. Ruta, "Does the global trade slowdown matter?", Journal of Policy Modeling, 2016, vol. 38, iss. 4, pp. 711-722. DOI: https://doi.org/10.1016/j.jpolmod.2016.05.013.

[2] J. P. Byrne, R. Sakemoto, and B. Xu, "Commodity price co-movement: heterogeneity and the time-varying impact of fundamentals", European Review of Agricultural Economics, jbz017. DOI: https://doi.org/10.1093/erae/jbz017.

[3] L. Kilian and X. Zhou, "Modeling fluctuations in the global demand for commodities", Journal of International Money and Finance, 2018, vol. 88, pp. 54-78. DOI: https://doi.org/10.1016/j.jimonfin.2018.07.001.

[4] M. Gachter and I. Gkrintzalis, "The finance-trade nexus revisited: Is the global trade slowdown also a financial story?", Economics Letters, 2017, vol. 158, pp. 21-22. DOI: https://doi.org/10.1016/ j.econlet.2017.05.037.

[5] A. Haigh, "Stocks Mixed on Light Volume; Treasuries Steady: Markets Wrap" [Electronic resource]. Available at: https://www.bloomberg.com/news (Accessed: 16 July 2019).

[6] Adam Haigh, "Stocks Trade Mixed Ahead of Powell Testimony: Markets Wrap" [Electronic resource]. Available at: https://www.bloomberg.com (Accessed: 10 July 2019).

[7] K. Pladson, "German Recession Seems to Be Inevitable, Investor Survey Shows" [Electronic resource]. Available at: https://www.bloomberg.com (Accessed: 08 July 2019).
[8] A. Haigh, "Asia Stocks Mixed as China Growth Data Assessed: Markets Wrap" [Electronic resource]. Available at: https://www.bloomberg.com (Accessed: 15 July 2019).

[9] "China's Growth Slides to Weakest Pace in Almost Three Decades", Bloomberg [Electronic resource]. Available at: https://www.bloomberg.com (Accessed: 15 July 2019).

[10] "Doing Business, Measuring Business Regulations", The World Bank Group, All Rights Reserved [Electronic resource]. Available at: https://www.doingbusiness.org/en/doingbusiness.

[11] "The World Bank Group, All Rights Reserved", [Electronic resource]. Available at: https://databank.worldbank.org.

[12] M. Tsygankova, "An evaluation of alternative scenarios for the Gazprom monopoly of Russian gas exports", Energy Economics, 2012, vol. 34, iss. 1, pp. 153-161. DOI: https://doi.org/10.1016/ j.eneco.2011.04.009.

[13] A. Radygin, Y. Simachev, and R. Entov, "The state-owned company: 'State failure' or 'market failure'?", Russian Journal of Economics, 2015, vol. 1, iss. 1, pp. 55-80. DOI: https://doi.org/10.1016/ j.ruje.2015.05.001.

[14] "GDP and industrial production in 2018: results of the year and growth prospects", Comments on the state and business, National Research University Higher School of Economics [Electronic resource]. Available at: https://dcenter.hse.ru/mirror/pubs/share/direct/244877266 (Accessed: 02 February 2019).

[15] S. Cabrales, R. Bautista, and J. Benavides, "A model to assess the impact of employment policy and subsidized domestic fuel prices on national oil companies", Energy Economics, 2017, vol. 68, pp. 566578. DOI: https://doi.org/10.1016/j.eneco.2017.10.038.

[16] R. Wagner, "Can the market value state-owned enterprises without privatizing them?", An application to natural resources companies, Resources Policy, 2018, vol. 59, pp. 282-290. DOI: https://doi.org/10.1016/j.resourpol.2018.07.015.

[17] J. Cooper, "The military dimension of a more Militant Russia", Russian Journal of Economics, 2016, vol. 2, iss. 2, pp. 129-145. DOI: https://doi.org/10.1016/j.ruje.2016.06.002.

[18] V. V. Smirnov, T. V. Talanova, A. N. Zakharova, G. S. Dulina, I. B. Getskina, and N. V. Huraskina, "Predictive Analysis of the Russian Entrepreneurship Development", Proceedings of the 32nd International Business Information Management Association Conference (IBIMA), 2018, pp. 6949-6958.

[19] V. Smirnov, V. Semenov, E. Kadyshev, A. Zakharova, and E. Perfilova, "Management of development efficiency of the Russian Economy", The European Proceedings of Social and Behavioural Sciences (SCT 2018), Published by the Future Academy, 2019, no. 218, pp. 1871-1877. ISSN: 2357-1330. DOI: https://dx.doi.org/ 10.15405/epsbs.2019.03.02.218.

[20] L. Chernykh, "Profit or politics? Understanding renationalizations in Russia", Journal of Corporate Finance, 2011, vol. 17, iss. 5, pp. $1237-$ 1253. DOI: https://doi.org/10.1016/j.jcorpfin.2011.06.009.

[21] C. D. D. Bo, M. Ferraris, and M. Florio, "Governments in the market for corporate control: Evidence from M\&A deals involving state-owned enterprises", Journal of Comparative Economics, 2017, vol. 45, iss. 1, pp. 89-109. DOI: https://doi.org/10.1016/j.jce.2016.11.006.

[22] C. Bruck, "The Predators' Ball: The Inside Story of Drexel Burnham and the Rise of the Junk Bond Raiders", Penguin (Non-Classics), 1989, $400 \mathrm{p}$.

[23] S. Oxenstierna, "Russia's defense spending and the economic decline", Journal of Eurasian Studies, 2016, vol. 7, iss. 1, pp. 60-70. DOI: https://doi.org/10.1016/j.euras.2015.06.001.

[24] J. Zhao and J. Tang, "Industrial structure change and economic growth: A China-Russia comparison", China Economic Review, 2018, vol. 47, pp. 219-233. DOI: https://doi.org/10.1016/j.chieco.2017.08.008.

[25] V. V. Smirnov, V. L. Semenov, E. N. Kadyshev, A. N. Zakharova, I. A. Guschin, T. V. Kravchenko, M. N. Yaklashkin, and O. A. Filippova, "Effective Public Administration of the Russian Economy", International Conference Communicative Strategies of Information Society (CSIS 2018), 2018. ISBN 978-94-6252-676-1. ISSN 23525398. DOI: https://doi.org/10.2991/csis-18.2019.13 (Accessed: 26 February 2019). 
Dynamics, 2015, vol. 32, pp. 11-24. DOI: https://doi.org/10.1016/j.strueco.2015.01.001.

[29] P. Castelnovo, C.F.D. Bo, and M. Florio, "Quality of institutions and productivity of State-Invested Enterprises: International evidence from major telecom companies", European Journal of Political Economy, 2019, vol. 58, pp. 102-117. DOI: https://doi.org/10.1016/ j.ejpoleco.2018.10.005

[30] L. Aaron and A. L. Bodoh-Creed, "Endogenous institutional selection, building trust, and economic growth", Games and Economic Behavior, 2019, vol. 114, pp. 169-176. DOI: https://doi.org/10.1016/j.geb.2019.01.005.
28] S. Storm and C.W.M. Naastepad, "Crisis and recovery in the German

economy: The real lessons", Structural Change and Economic on Russia's ruble", Journal of Comparative Economics, 2016, vol. 44 S. Kailitz and A. Umland, "How post-imperial democracies die: A . and Post-Communist Studies, 2019, vol. 52, iss. 2, pp. 105-115. DOI: https://doi.org/10.1016/j.postcomstud.2019.05.003 